\title{
An Uncharacterized Protein from the Metagenome with no Obvious Homology to known Lipases Shows Excellent Alkaline Lipase Properties and Potential Applications in the Detergent Industry
}

\section{Gang Li ( $\sim$ lsslig@mail.sysu.edu.cn )}

Sun Yat-sen University School of Life Science https://orcid.org/0000-0003-1550-1724

Yue Xiao

Sun Yat-sen University School of Life Science

Yi-De Liu

Sun Yat-sen University School of Life Science

Ge Yuan

Sun Yat-sen University School of Life Science

\section{Run-Qian Mao}

Institute of Zoology, Guangdong Academy of Sciences

\section{Research Article}

Keywords: Lipase, Functional metagenomics, Low homology, Alkali-resistance, Detergent compatibility

Posted Date: October 21st, 2021

DOI: https://doi.org/10.21203/rs.3.rs-941575/v1

License: (c) (1) This work is licensed under a Creative Commons Attribution 4.0 International License.

Read Full License 


\section{Abstract}

A novel lipase, Lip486, which has no obvious homology with known lipases, was discovered using functional metagenomics technology. Phylogenetic tree analysis suggested that the enzyme belongs to a new subfamily called lipolytic enzyme family II. To explore the enzymatic properties, lip486 was expressed heterologously and efficiently in Escherichia coli. The recombinant enzyme displayed the highest activity on the substrate $p$-nitrophenyl caprate with a carbon chain length of 10 , and its optimum temperature and $\mathrm{pH}$ were $53^{\circ} \mathrm{C}$ and 8.0, respectively. The recombinant Lip486 showed good activity and stability in strong alkaline and medium-low -temperature environments. The results of compatibility and soaking tests showed that the enzyme had good compatibility with 4 kinds of commercial detergents, and an appropriate soaking time could further improve the enzyme activity. Oil stain removal test results for a cotton cloth indicated that the washing performance of commercial laundry detergent supplemented with Lip486 was further improved. In addition, as one of the smallest lipases found to date, Lip486 also has the advantages of high yield, good stability and easy molecular modification. These characteristics reflect the good application prospects for Lip486 in the detergent and other industries in the future.

\section{Introduction}

Lipase (EC3.1.1.3) is a special type of ester bond hydrolase that can catalyze the hydrolysis of triacylglycerides and decompose various natural oils and fats produced by organisms. Lipases belong to the large family of lipolytic enzymes but obviously prefer long-chain acylglycerols (carbon atom numbers >10). Lipase acts as a catalyst at the oil-water interface and can catalyze transesterification, synthesis, hydrolysis and ammonolysis reactions in the nonaquesous phase (Casas-Godoy et al. 2012), which has great research and development value, rendering lipase the third most important industrial enzyme after protease and glycosyl hydrolase (Martínez-Ruiz et al. 2018).

Lipase sources are very broad given that animals, plants, and microorganisms can produce lipases (Patel et al. 2019). However, lipases derived from microorganisms have more biodiversity than those from animals and plants. These lipases have many types and a wider operating temperature range, and the stability and activity of microbial lipases are higher. Furthermore, microorganisms have the characteristics of fast growth, a short reproductive cycle and easy cultivation and are thus more suitable for large-scale industrial production (Contesini et al. 2010). Lipase has a wide range of industrial applications, including food, washing, papermaking, environmental management, bioenergy, cosmetics, oil processing and other fields (Bharathi and Rajalakshmi 2019; Navvabi et al. 2018; Priyanka et al. 2019).

The washing industry is an important application field for lipase. A detergent containing lipase has many advantages, including reduced washing times, stirring rates and washing temperatures, and can extend the life of textile clothes. At the same time, the use of lipase can also reduce the amount of surfactant used, which is conducive to environmental protection (Ugo et al. 2017). According to reports, at least 13 
billion tons of detergents in the washing industry require the addition of 1,000 tons of lipase every year (Jaeger and Reetz, 1998). At present, all lipases that can be added to detergents are alkaline lipases, and their optimum $\mathrm{pH}$ is $8.0-12.0$. These lipases are mainly produced by some cultivable microorganisms, such as Bacillus (Niyonzima and More 2014; Gricajeva et al. 2016) and Pseudomonas (Phukon et al. 2020). Considering the composition of detergents, an ideal lipase for detergent addition should have the following characteristics: high activity, a wide reaction temperature and $\mathrm{pH}$, and strong resistance to alkali, organic solvents, metal ions and other chemical substances (Salihu and Alam 2015). However, the enzymatic properties of lipases currently used in the washing industry rarely meet the above requirements, and their activity and stability in detergents require further improvement. Therefore, identifying more stable and efficient alkaline lipases from the natural world is still an urgent and necessary task.

Approximately $85 \%$ of papermaking enterprises in China adopt the alkaline method. The production process mainly uses lime to steam straw, wheat straw and other wood fiber raw materials to produce pulp. The discharged wastewater contains a large amount of alkaline substances such as $\mathrm{NaOH}$ and $\mathrm{Na}_{2} \mathrm{SO}_{4}$, and its $\mathrm{pH}$ is strongly alkaline. In addition, the sediments of papermaking wastewater are rich in lipids, alkaline substances, organic solvents, heavy metal ions and other components (Milferstedt et al. 2012). Microorganism living in this habitat should have a strong ability to degrade lipid molecules and be able to withstand strong alkali, organic solvents and heavy metal ions. Thus, papermaking wastewater sediment is an ideal sampling material for isolating lipases with potential for washing industrial applications.

Although microorganisms are abundant in nature, less than $1 \%$ of them can be isolated and cultured under laboratory conditions (Torsvik et al. 1996). Therefore, isolating novel catalysts from the environment using conventional pure culture methods is increasingly difficult. The emergence of metagenomic technology has provided a powerful research tool to solve the above problems. The metagenomic method can identify a large number of valuable catalysts from uncultivated microorganisms by directly extracting DNA from environmental samples and constructing libraries (Madhavan et al. 2017). Since the advent of this technique, many diverse enzymes with a variety of application prospects have been identified using samples from various habitats (Ngara and Zhang 2018). Recently, some novel lipases have been identified in different enviroments through metagenomic technology, including a bovine rumen (Privé et al. 2015), an oil-polluted mud flat (Kim et al. 2015), mangrove forest soil (Tang et al. 2017), fat-contaminated soil (Almeida et al. 2019), hot springs (Sahoo et al. 2020), etc. However, to the best of our knowledge, few reports are available on the discovery of lipases from the sediment of papermaking wastewater, which can be used in the washing industry.

In this study, we selected the wastewater sediments of an alkaline paper mill with a history of more than 30 years in Xuchang City, Henan Province, China, as the test samples, constructed a metagenomic library, and identified a novel lipase, Lip486, with no obvious homology with known lipases from the library. We conducted a detailed study on the enzymatic properties of Lac486 and initially explored the potential of this enzyme as a detergent additive. 


\section{Materials And Methods}

Strains, vectors, and chemical reagents

The strains used in this study were Escherichia coli (E. coli) DH5a and BL21 (DE3), and the vectors used were pUC118 (TaKaRa, Dalian, China) and pET32a (Novagen, Madison, WI, USA). The restriction endonuclease and ligase used in vector construction were purchased from the TaKaRa company, and DNA extraction and purification kits were purchased from Qiagen (Hilden, Germany). Other chemical reagents used were all analytically pure and were obtained from Sigma-Aldrich (St. Louis, MO, USA) or Sangon Biotech (Shanghai, China).

Metagenomic library construction and lipolytic enzyme screening

The sediment samples from papermaking wastewater used in this study were collected from a paper mill $\left(34^{\circ} 02^{\prime} 15^{\prime \prime} \mathrm{N}, 113^{\circ} 51^{\prime} 28^{\prime \prime} \mathrm{E}\right)$ in Xuchang City, Henan Province, China. The genomic DNA of the samples was extracted using a QIAamp DNA Stool Mini Kit (Qiagen) according to the manufacturer's instructions. The extracted DNA was partially digested with EcoRI, and 2-8 kb DNA fragments were recovered with a gel extraction kit (Qiagen). After ligating the recovered DNA fragment with the library construction vector pUC118, E. coli DH5a was transformed via electroporation. The transformed cells were incubated on LB selection medium containing $1.0 \mathrm{mM}$ isopropyl- $\beta$-D-1-thiogalactopyranoside (IPTG), $1 \%$ tributyrin, and $100 \mu \mathrm{g} / \mathrm{mL}$ ampicillin to screen for lipolytic enzyme-positive clones. Clones with a transparent circle around the colony were considered lipolytic enzyme-positive clones. All positive clones were sent to Sangon Biotech for sequencing.

DNA sequence analysis of positive clones and lipase phylogenetic tree construction

An insertion fragment sequenced from a positive clone was used to search for possible open reading frames (ORFs) of lipolytic enzymes with ORF Finder software of the NCBI (http://www.ncbi.nlm.nih.gov/). Protein sequence similarity was searched using the NCBI BLAST program. The members of several lipolytic enzyme families that have certain homology with the identified lipase were first analyzed for sequence similarity using Clustal W software (http://www.ebilac.uk/clustalw/), and then the results were used to construct a phylogenetic tree according to the neighbor-joinning method with MEGA 7.0 software to obtain the species information of the identified lipase and its genetic relationships (Kumar et al. 2016).

Bioinformatics analysis of Lip486

The online analysis software ExPASy ProtParam tool (http://web.expasy.org/protparam/) was used to analyze the amino acid isoelectric point, molecular weight, half-life, instability and hydropathicity of Lip486. TMHMM 2.0 (Käll et al. 2004) and SignalP 4.0 servers (Petersen et al. 2011) were used to analyze the transmembrane region and signal peptide sequence of Lip486.

Heterologous expression of lip486 and purification of the recombinant enzyme 
To study the enzymatic properties of Lip486, PCR technology was used to amplify lip486. The two primers used were lip486-forward (5'- CCG GAATTC Atg agc cgg atc gta gcc ctg ccg ggc gat g-3') and lip486-reverse (5'- CCC AAGCTT Acg gct gcc gac ggc cgc cgg gtc gag agc ttC-3'). The underlined parts in the two primers represent two restriction enzyme cleavage sites. After double digestion, the amplified lip486 was ligated with the same digested expression vector pET32a for $12 \mathrm{~h}$, and then the ligation product was transformed into $E$. coli BL21(DE3) by electroporation. Next, the transformed cells were spread onto LB screening plates containing tributyrin, and cultured at $37^{\circ} \mathrm{C}$ for $36 \mathrm{~h}$ to observe whether a transparent circle formed around the colony. To produce and purify the recombinant enzyme, the identified transformant was first inoculated into LB medium and cultured at $37^{\circ} \mathrm{C}$ until the $\mathrm{OD}_{600}$ reached 0.8 . Then, the culture was induced with $0.28 \mathrm{mM} \mathrm{IPTG}$ at $30^{\circ} \mathrm{C}$ and $180 \mathrm{rpm}$ for $16 \mathrm{~h}$. Cells were collected by centrifugation, washed twice with pure water and resuspended in PBS buffer. Cells were then broken by ultrasonic wave. Cellular lysates were centrifuged to obtain the crude enzyme solution, which was further purified by a Ni-NTA Sefinose Column (Sangon Biotech) according to the manufacturer's manual. The resulting pure enzyme was stored at $4^{\circ} \mathrm{C}$ for further study.

SDS-PAGE and western blot analysis of Lip486

The molecular weight of the recombinant Lip486 was analyzed by SDS-PAGE, and the molecular weight standard was obtained from Tiangen Biotech (Beijing, China). The western blot analysis is briefly described as follows: First, recombinant Lip486 was analyzed by SDS-PAGE, and then the protein bands from the gel were transferred to a PVDF membrane using a semidry tansfer system (Trans-Blot SD type, Bio-Rad, Hercules, California, USA). The recombinant Lip486 was then incubated at room temperature for $2 \mathrm{~h}$ with a 1,000-fold dilution of antibody I (mouse anti-histidine antibody), and after washing, the membrane was incubated with antibody II (IgG goat anti-mouse antibody, conjugated with HRP) diluted 5,000 times at room temperature for $2 \mathrm{~h}$. Finally, NBT (nitro-blue-tetrazolium)-BCIP (5-bromo-4-chloro-3indolyl-phosphate) reagent (Sangon Biotech) was added to develop color in the dark, and the band of the target protein was observed.

Lip486 enzyme activity analysis

First, $10 \mu \mathrm{L}$ of appropriately diluted enzyme solution was added to a reaction system consisting of 390 $\mu \mathrm{L}$ of the following ingredients: $10 \mu \mathrm{L}$ of $1 \mathrm{mM}$ p-nitrophenol ester and $380 \mu \mathrm{L}$ of $40 \mathrm{mM}$ Britton-Robinson buffer ( $\mathrm{pH} 8.0)$, which were reacted at $53^{\circ} \mathrm{C}$ for $20 \mathrm{~min}$, and $95 \%$ ethanol was added to stop the reaction. The absorbance at $405 \mathrm{~nm}$ was measured by a microplate reader. One unit of lipase activity is defined as the amount of enzyme required to hydrolyze the substrate to produce $1 \mu \mathrm{mol}$ of $p$-nitrophenol per minute. Enzyme activity was measured three times, and the average value was taken.

Characterization of the recombinant Lip486

To detect the specificity of the recombinant Lip486 to substrates with different carbon chain lengths, different substrates with a final concentration of $1 \mathrm{mM}$ were added into the reaction system at $53^{\circ} \mathrm{C}$ and $\mathrm{pH} 8.0$, including $p$-nitrophenyl butyrate (C4), p-nitrophenyl caproate (C6), p-nitrophenyl octanoatee (C8), 
$p$-nitrophenyl caprate (C10), $p$-nitrophenyl laurate (C12), $p$-nitrophenyl myristate (C14), and $p$-nitrophenyl palmitate (C16); $95 \%$ ethanol was added to terminate the reaction. The absorbance value of each reaction was detected at a wavelength of $405 \mathrm{~nm}$, and the maximum value of enzyme activity was defined as $100 \%$. The optimal substrate of Lip486 was determined after plotting the relative enzyme activity and then used to study the enzymatic properties of Lip486. The optimum pH was measured at a temperature of $53^{\circ} \mathrm{C}$, and the $\mathrm{pH}$ range was $5.0-12.0$. $\mathrm{pH}$ stability was measured by incubating Lip486 at $\mathrm{pH}$ 8.0, 9.0 10.0, 11.0 and 12.0 for $1 \mathrm{~h}, 2 \mathrm{~h}, 3 \mathrm{~h}$ and $4 \mathrm{~h}$, at $4{ }^{\circ} \mathrm{C}$, and then the residual activity of the enzyme was measured. The initial enzyme activity was defined as $100 \%$, and the relative enzyme activity after incubation was plotted against $\mathrm{pH}$. The optimum temperature was investigated at $\mathrm{pH} 8.0$, and the temperature range was $4{ }^{\circ} \mathrm{C}-70^{\circ} \mathrm{C}$. Temperature stability was investigated by incubating the enzyme at 4 ${ }^{\circ} \mathrm{C}, 30^{\circ} \mathrm{C}, 40^{\circ} \mathrm{C}, 50{ }^{\circ} \mathrm{C}$ and $60^{\circ} \mathrm{C}$ for $1 \mathrm{~h}, 2 \mathrm{~h}, 3 \mathrm{~h}$, and $4 \mathrm{~h}$ at $\mathrm{pH} 8.0$ and then measuring the residual enzyme activity. The initial enzyme activity was defined as $100 \%$, and the relative enzyme activity after incubation was plotted against temperature.

Kinetic parameter determination

The optimal substrate was selected to measure the kinetic parameters of Lip486. Substrates with final concentrations of $0 \mathrm{mM}, 0.1 \mathrm{mM}, 0.25 \mathrm{mM}, 0.5 \mathrm{mM}, 0.75 \mathrm{mM}, 1.0 \mathrm{mM}, 1.25 \mathrm{mM}, 1.5 \mathrm{mM}$ and $1.75 \mathrm{mM}$ were added and reacted with $20 \mu \mathrm{L}$ pure enzyme in $0.1 \mathrm{M}$ phosphate buffer $(\mathrm{pH} 8.0)$ for 20 min in the buffer solution with the optimal pH at the optimal temperature, and then $100 \mu \mathrm{L} 20 \%$ SDS was added to terminate the reaction. The absorbance value of the reaction solution was determined at $405 \mathrm{~nm}$.

According to the enzyme activity, a Lineweaver-Burk double reciprocal diagram was constructed, and the kinetic parameters $K_{\mathrm{m}}$ and $K_{\text {cat }}$ of Lac486 were obtained. Then, the catalytic efficiency $\left(K_{\text {cat }} / K_{\mathrm{m})}\right.$ of the enzyme for the optimal substrate was calculated.

Effects of metal ions, organic solvents, and other chemical reagents on Lip486

The effects of three concentrations $(1 \mathrm{mM}, 5 \mathrm{mM}$, and $10 \mathrm{mM})$ of metal ions $\left(\mathrm{Zn}^{2+}, \mathrm{Mg}^{2+}, \mathrm{Ca}^{2+}, \mathrm{Mn}^{2+}\right.$, $\mathrm{Cu}^{2+}, \mathrm{Ni}^{2+}, \mathrm{Fe}^{2+}$, and $\left.\mathrm{Na}^{+}\right)$, three concentrations $(1 \%, 15 \%$, and $30 \%, \mathrm{v} / \mathrm{v})$ of organic solvents (acetonitrile, methanol, ethanol, and isopropanol), and different concentrations of chemical reagents, including EDTA $(10 \mathrm{mM}, 25 \mathrm{mM}$, and $50 \mathrm{mM})$, SDS (1 mM, $5 \mathrm{mM}$, and $10 \mathrm{mM})$, Tween-20 $(0.1 \%, 1 \%$, and $10 \%, \mathrm{w} / \mathrm{v})$, Tween-80 $(0.1 \%, 1 \%$, and $10 \%, \mathrm{w} / \mathrm{v})$, and Triton X-100 $(0.1 \%, 1 \%$, and $10 \%, \mathrm{w} / \mathrm{v})$, were tested after the addition of each target reagent to enzyme solutions for $1 \mathrm{~h}$ at $53^{\circ} \mathrm{C}$ and $\mathrm{pH} 8.0$. All tests were repeated three times, and enzyme activity without the target reagent was defined as $100 \%$.

Compatibility test of the recombinant Lip486 with several commercial detergents

We selected the four most common, large-scale wash products in the Chinese market, including Tide detergent, Blue Moon detergent, Dettol hand sanitizer and Liby detergent for the test. According to the production instructions, the final concentration of Tide detergent was $7 \mathrm{mg} / \mathrm{mL}$, and the final concentrations of Blue Moon detergent, Dettol hand sanitizer and Liby detergent were $1 \%(\mathrm{v} / \mathrm{v})$. Then, the same volume of a lipase solution $(10 \mathrm{U} / \mathrm{mL})$ as the detergent was added to each solution to be tested. 
The $\mathrm{pH}$ values of the mixed solution were 9.50, 7.90, 8.06 and 7.84. After $1 \mathrm{~h}, 2 \mathrm{~h}, 3 \mathrm{~h}, 4 \mathrm{~h}, 6 \mathrm{~h}$, and $24 \mathrm{~h}$ of incubation at room temperature, the residual enzyme activity was measured under standard conditions. The test was repeated three times, and the enzyme activity without detergent was defined as $100 \%$.

Immersion test of the recombinant Lip486 in several commercial detergents

According to conventional practices, $10 \mathrm{~g}$ of detergent should be added to each $\mathrm{kg}$ of clothing in $5 \mathrm{~L}$ water for soaking. At this dose, $10 \mathrm{~g}$ of various detergents was added to $5 \mathrm{~L}$ of water, and then $10 \mathrm{~mL}$ of lipase solution $(10 \mathrm{U} / \mathrm{mL}$ ) was added for $10 \mathrm{~min}, 20 \mathrm{~min}$ and $30 \mathrm{~min}$. Then, the residual enzyme activity of Lip486 was detected. The soaking test was repeated three times, and the enzymatic activity without detergent treatment was defined as $100 \%$.

Determination of the ability of the recombinant Lip486 to remove oil stains from cotton cloth

Four pieces of white cotton cloth with a same size $(4 \mathrm{~cm} \cdot 4 \mathrm{~cm})$ were cut, soaked in cooking oil for $24 \mathrm{~h}$, removed and air-dried. The four pieces of cloth were divided into $A, B, C$, and $D$, and then the following different treatments were performed: A: oil-stained cloth + tap water; B: oil-stained cloth + tap water + thermally deactivated Blue Moon detergent $(0.2 \%)$; C: oil-stained cloth + tap water + Blue Moon detergent $(0.2 \%)$; and D: oil-stained cloth + tap water + thermally deactivated Blue Moon detergent $(0.2 \%)+$ Lip486 solution $(0.5 \mathrm{~mL}, 10 \mathrm{U})$. The four groups of white cloth were washed $(150 \mathrm{rpm})$ at room temperature for 30 min, rinsed with tap water 3 times and air-dried. Photos were taken, and the percentage of oil stain removal from the four pieces of white cloth was recorded.

The accession number of lip486

The accession number of lip486 (GenBank database) is MZ396074.

\section{Results}

Screening of esterase genes

A metagenomic library containing approximately 20,000 clones was constructed. The results of restriction digestion of recombinant clones showed that the length of inserts in the library ranged from 1.0 to $7.0 \mathrm{~kb}$, with an average length of approximately $3.8 \mathrm{~kb}$. Based on this estimate, the total amount of microbial DNA contained in this library was approximately $76 \mathrm{MB}$. A total of 8 positive esterase clones were screened from the library by functional screening with tributyrin as the substrate. The esterasepositive clones (EST18) that produced the largest transparent circle was selected for follow-up studies.

Sequence analysis of the esterase-positive clone

The selected positive clone was sequenced, which was found to contain an insert of $1696 \mathrm{bp}$. Using ORF finder software on the NCBI website, an ORF sequence (486 bp) of unknown function was found in the insert. The gene encodes a protein consisting of 161 amino acids with a theoretical molecular weight of 
$17.36 \mathrm{kDa}$. BLAST comparison suggested that the protein encoded by this gene has the greatest similarity (only $41 \%$ ) to an uncharacterized protein from Nitrospirillum amazonense Y2. Therefore, the function of the gene cannot be identified based on BLAST homology comparison results. Because the gene was obtained by the esterase function screening method and subsequent experimental results proved that its optimal substrate is long-chain fatty acids (C-chain length $\geqq 10$ ), we concluded that the gene is a lipase gene and named it lip486. Most esterases mainly belong to 8 families. To identify the esterase family to which Lip486 belongs, the sequences of several typical members from each of the eight esterase families were selected, and a phylogenetic tree was constructed together with the sequence of Lip486. The results are shown in Figure 1. Figure 1 shows that Lip486 and its homologs belong to lipolytic enzyme family II but may belong to a new subfamily.

Bioinformatics analysis of Lip486

Several software programs were used to analyze the molecular weight, isoelectric point, half-life, instability coefficient, hydrophilicity, transmembrane domain of amino acids and signal peptide sequence of Lip486. The results are shown in Table 1. The results in Table 1 indicate that the isoelectric point of Lip486 is slightly acidic, and the protein has good stability. However, its hydrophilicity is not high. Moreover, Lip486 is located outside the cell membrane and has no signal peptide sequence.

Table 1

Bioinformatics analysis of Lip486

\begin{tabular}{|llllllll|}
\hline Name & $\begin{array}{l}\text { Molecular } \\
\text { weight }\end{array}$ & $\begin{array}{l}\text { Isoelectric } \\
\text { point }\end{array}$ & Half-life & Instability & GRAVY $^{\mathrm{a}}$ & TMHMM $^{\text {b }}$ & SignalPc $^{\text {TM }}$ \\
\hline Lip486 & $17.36 \mathrm{KDa}$ & 6.29 & $30 \mathrm{~h}$ & Stable (38.88) & -0.49 & outside & No \\
\hline
\end{tabular}

a:GRAVY is the abbreviation of "Grand average of hydropathicity", and the bigger the negative value, the better the hydrophilicity.

b: TMHMM refers to the possible locations of proteins in the membrane, including transmembrane, inside and outside.

c: SignalP refers to whether the gene encoding the target protein has a signal peptide sequence.

Heterologous expression of lip486 and purification of the recombinant enzyme

The lip486 gene was inserted into the prokaryotic expression vector pET32a and transformed into $E$. coli BL21(DE3), and the function of the recombinant protein was preliminarily verified on a screening plate containing tributyrin. The results suggested that the recombinant clones produced obvious hydrolysis circles on the screening plate (Figure 2), which demonstrated that the recombinant protein can decompose the tributyrin substrate. After expression of the recombinant protein was induced, it was purified with a Ni-NTA-Sefinose Column. After purification treatment, the crude enzyme solution showed 8.62-time purification and an $86.49 \%$ activity yield (Table 2 ). SDS-PAGE was performed using the supernatant (crude enzyme solution) obtained after ultrasonic cell disruption, and the enzyme solution 
was simultaneously purified with a Ni-NTA-Sefinose Column (Figure 3). A very thick target protein band appeared near $35 \mathrm{kDa}$ on the electrophoresis graph, and its size was basically consistent with the theoretically calculated molecular weight $(17.36 \mathrm{kDa})$ of Lip486 plus the molecular weight of the His tag (17 kDa). In addition, the His tag carried by the recombinant protein was also confirmed by the western blot results (Figure 3, Lane 3). SDS-PAGE and western blot results indicated that the high soluble expression of lip486 was obtained in E. coli. After optimizing the expression conditions, the highest expression level reached $219.62 \mathrm{mg} / \mathrm{L}$, and the specific enzyme activity of the purified enzyme was 51.80 $\mathrm{U} / \mathrm{mg}$.

Table 2

Purification of Lip486 recombinant protein from E. coli BL21 (DE3) carrying lip486 gene

\begin{tabular}{|llllll|}
\hline Purification step & $\begin{array}{l}\text { Total } \\
\text { protein } \\
(\mathbf{m g})\end{array}$ & $\begin{array}{l}\text { Total } \\
\text { activity }(\mathrm{U})\end{array}$ & $\begin{array}{l}\text { Specific activity } \\
(\mathrm{U} / \mathrm{mg})\end{array}$ & $\begin{array}{l}\text { Purification } \\
\text { fold }\end{array}$ & $\begin{array}{l}\text { Activity } \\
\text { yield } \\
\text { (\%) }\end{array}$ \\
\hline Cell lysate & 77.53 & 465.98 & 6.01 & 1.00 & $100 \%$ \\
\hline $\begin{array}{l}\text { His-Tag affinity } \\
\text { chromatography }\end{array}$ & 7.78 & 403.01 & 51.80 & 8.62 & $86.49 \%$ \\
\hline
\end{tabular}

Characterization of the recombinant Lip486

Using $p$-nitrophenyl fatty acid esters with different carbon chain lengths, the substrate specificity of Lip486 was investigated (Figure 4A). The results showed that Lip486 had the highest hydrolysis activity on the $\mathrm{C} 10$ substrate $p$-nitrophenyl caprate, and its hydrolysis activity on substrates with a carbon chain length greater than 10 was significantly higher than that on substrates with a carbon chain length below 10 , indicating that Lip486 is a lipase of esterases. Lip486 exhibited the highest activity at $53^{\circ} \mathrm{C}$ (Figure 4B) and maintained more than $70 \%$ of its highest activity in the range of $40-60{ }^{\circ} \mathrm{C}$, indicating that the enzyme was suitable for hydrolysis of substrates at higher temperatures. In addition, Lip486 demonstrated excellent thermostability at several temperatures $\left(4{ }^{\circ} \mathrm{C}, 30^{\circ} \mathrm{C}, 40^{\circ} \mathrm{C}, 50^{\circ} \mathrm{C}, 60^{\circ} \mathrm{C}\right)(\mathrm{Fig} .4 \mathrm{C})$, especially when incubated at $60^{\circ} \mathrm{C}$ for $4 \mathrm{~h}$. The residual enzyme activity was still greater than $60 \%$ of the highest activity, suggesting that the enzyme has the potential for application in the industrial field at higher temperatures. The optimum pH of Lip486 was 8.0 (Fig. 4D), and more than $80 \%$ of the highest enzyme activity was retained in the $\mathrm{pH}$ range of 7.8 to 10.0 , but almost no enzyme activity was detected at $\mathrm{pH}$ values below 7.0, indicating that Lip486 is an alkaline lipase. In the pH stability test, when Lip486 was incubated at $\mathrm{pH} 10.0$ and 11.0 for $4 \mathrm{~h}$, the residual enzyme activity was still $60 \%$ and $50 \%$ of the highest enzyme activity (Fig. 4E), respectively, revealing that Lip486 is an alkaline lipase with high enzyme activity and good stability under alkaline conditions and has good application potential in fields involving strong alkaline environments (such as the washing industry). The kinetic parameters of Lip486 were analyzed using $p$-nitrophenyl caprate as the substrate, revealing that the $K_{\mathrm{m}}$ was $0.53 \mathrm{mM}$ and the $K_{\text {cat }}$ was $452.16 \mathrm{~S}^{-1}$. Based on these two parameters, the catalytic efficiency was calculated to be 853.13 $\mathrm{s}^{-1} \mathrm{mM}^{-1}$. 
Effects of metal ions, organic solvents, and other chemical reagents on Lip486

Different metal ions had different effects on enzyme activity (Table 3). $\mathrm{Cu}^{2+}, \mathrm{Ni}^{2+}$ and $\mathrm{Fe}^{2+}$ substantially increased the enzyme activity of Lip486 at a high concentration of $25 \mathrm{mM}$ but significantly inhibited enzymatic activity at a low concentration of $1 \mathrm{mM}$. In contrast, $\mathrm{Ca}^{2+}$ and $\mathrm{Na}^{+}$obviously promoted enzymatic activity at low concentrations of $1 \mathrm{mM}$ and $5 \mathrm{mM}$, but enzyme activity decreased sharply at a high concentration of $25 \mathrm{mM}$. In addition, most organic solvents significantly increased the activity of Lip486, especially alcohols. Methanol, ethanol and isopropanol increased the enzyme activity of Lip486 by approximately $15-, 23-$ and 22 -fold, respectively, at a high concentration $(30 \%, v / v)$. However, acetonitrile significantly inhibited the activity of Lip486, rendering it completely inactivated. Lip486 also had good compatibility with three surfactants: Tween-20, Tween-80 and Triton X-100. Two concentrations $(0.1 \%$ and $1 \%, w / v)$ of Tween-20 and three concentrations $(0.1 \%, 1 \%$ and $10 \%, w / v)$ of Tween-80 and Triton X-100 could increase its enzyme activity by approximately $2-9$ times. 
Table 3

Effects of metal ions, organic solvents, and other chemical reagents on Lip486.

\begin{tabular}{|c|c|c|c|c|c|}
\hline $\begin{array}{l}\text { Metal } \\
\text { ions }\end{array}$ & Concentration & $\begin{array}{l}\text { Relative } \\
\text { activity (\%) }\end{array}$ & $\begin{array}{l}\text { Organic solvens and } \\
\text { other chemical } \\
\text { reagents }\end{array}$ & Concentration & $\begin{array}{l}\text { Relative } \\
\text { activity } \\
(\%)\end{array}$ \\
\hline \multirow[t]{2}{*}{ Control } & 0 & 100 & Control & 0 & 100 \\
\hline & $1 \mathrm{mM}$ & NA & & $1 \%(v / v)$ & NA \\
\hline \multirow[t]{3}{*}{$\mathrm{Zn}^{2+}$} & $5 \mathrm{mM}$ & NA & Acetonitrile & $15 \%(\mathrm{v} / \mathrm{v})$ & NA \\
\hline & $25 \mathrm{mM}$ & $356.80 \pm 0.73$ & & $30 \%(v / v)$ & NA \\
\hline & $1 \mathrm{mM}$ & $77.72 \pm 0.91$ & & $1 \%(v / v)$ & $150.92 \pm 3.05$ \\
\hline \multirow[t]{3}{*}{$\mathrm{Mg}^{2+}$} & $5 \mathrm{mM}$ & $36.95 \pm 0.35$ & Methanol & $15 \%(v / v)$ & $999.76 \pm 1.12$ \\
\hline & $25 \mathrm{mM}$ & NA & & $30 \%(v / v)$ & $1585.72 \pm 6.15$ \\
\hline & $1 \mathrm{mM}$ & $126.21 \pm 1.11$ & & $1 \%(\mathrm{v} / \mathrm{v})$ & $270.92 \pm 8.21$ \\
\hline \multirow[t]{3}{*}{$\mathrm{Ca}^{2+}$} & $5 \mathrm{mM}$ & $111.70 \pm 0.58$ & Ethanol & $15 \%(\mathrm{v} / \mathrm{v})$ & $576.55 \pm 4.36$ \\
\hline & $25 \mathrm{mM}$ & $17.42 \pm 0.53$ & & $30 \%(v / v)$ & $2376.58 \pm 3.82$ \\
\hline & $1 \mathrm{mM}$ & $69.63 \pm 0.39$ & & $1 \%(v / v)$ & $62.14 \pm 4.04$ \\
\hline \multirow[t]{3}{*}{$\mathrm{Mn}^{2+}$} & $5 \mathrm{mM}$ & $121.05 \pm 0.61$ & Isopropanol & $15 \%(v / v)$ & $389.17 \pm 5.06$ \\
\hline & $25 \mathrm{mM}$ & $78.94 \pm 1.32$ & & $30 \%(v / v)$ & $2298.80 \pm 6.52$ \\
\hline & $1 \mathrm{mM}$ & $22.91 \pm 0.60$ & & $10 \mathrm{mM}$ & $153.31 \pm 0.13$ \\
\hline \multirow[t]{3}{*}{$\mathrm{Cu}^{2+}$} & $5 \mathrm{mM}$ & $39.90 \pm 0.59$ & EDTA & $25 \mathrm{mM}$ & $392.54 \pm 0.72$ \\
\hline & $25 \mathrm{mM}$ & $179.42 \pm 2.60$ & & $50 \mathrm{mM}$ & $1225.47 \pm 0.54$ \\
\hline & $1 \mathrm{mM}$ & $49.46 \pm 0.91$ & & $1 \mathrm{mM}$ & $90.40 \pm 1.32$ \\
\hline \multirow[t]{3}{*}{$\mathrm{Ni}^{2+}$} & $5 \mathrm{mM}$ & $197.82 \pm 0.72$ & SDS & $5 \mathrm{mM}$ & $82.21 \pm 3.92$ \\
\hline & $25 \mathrm{mM}$ & $381.85 \pm 0.89$ & & $10 \mathrm{mM}$ & $47.61 \pm 2.55$ \\
\hline & $1 \mathrm{mM}$ & $71.44 \pm 1.90$ & & $0.1 \%(w / v)$ & $265.20 \pm 5.32$ \\
\hline \multirow[t]{3}{*}{$\mathrm{Fe}^{2+}$} & $5 \mathrm{mM}$ & $211.11 \pm 0.60$ & Tween-20 & $1 \%(w / v)$ & $322.55 \pm 4.15$ \\
\hline & $25 \mathrm{mM}$ & $396.52 \pm 0.51$ & & $10 \%(w / v)$ & NA \\
\hline & $1 \mathrm{mM}$ & $586.61 \pm 0.67$ & & $0.1 \%(w / v)$ & $329.74 \pm 4.21$ \\
\hline
\end{tabular}

NA: No activity. 


\begin{tabular}{|llllll|}
\hline $\begin{array}{l}\text { Metal } \\
\text { ions }\end{array}$ & Concentration & $\begin{array}{l}\text { Relative } \\
\text { activity (\%) }\end{array}$ & $\begin{array}{l}\text { Organic solvens and } \\
\text { other chemical } \\
\text { reagents }\end{array}$ & Concentration & $\begin{array}{l}\text { Relative } \\
\text { activity } \\
\text { (\%) }\end{array}$ \\
\hline $\mathrm{Na}^{+}$ & $5 \mathrm{mM}$ & $239.23 \pm 0.89$ & Tween-80 & $1 \%(\mathrm{w} / \mathrm{v})$ & $652.27 \pm 3.36$ \\
& $25 \mathrm{mM}$ & $\mathrm{NA}$ & & $10 \%(\mathrm{w} / \mathrm{v})$ & $281.05 \pm 3.22$ \\
& & & $0.1 \%(\mathrm{w} / \mathrm{v})$ & $290.73 \pm 0.22$ \\
& & Triton X-100 & $1 \%(\mathrm{w} / \mathrm{v})$ & $684.38 \pm 6.51$ \\
\hline NA: No activity. & & & $10 \%(\mathrm{w} / \mathrm{v})$ & $982.72 \pm 4.04$ \\
\hline
\end{tabular}

Compatibility test of the recombinant Lip486 with several commercial detergents

The compatibilities of Lip486 with several commercial detergents are shown in Figure 5. Lip486 was most compatible with Blue Moon detergent, with more than $55 \%$ of the highest enzyme activity after incubation for $24 \mathrm{~h}$ at room temperature. However, it had relatively moderate compatibility with Tide detergent, with the enzyme activity decreasing by approximately half after incubation for $3 \mathrm{~h}$. In addition, the compatibility of Lip486 with Liby detergent and Dettol hand sanitizer was also good, with residual enzyme activities after incubation for $4 \mathrm{~h}$ of approximately $60 \%$ and $80 \%$ of the highest activity, respectively. In general, Lip486 has good compatibility with most commercial detergents.

Immersion test of the recombinant Lip486 in several commercial detergents

To evaluate the performance of Lip486 in the laundry process, immersion tests of Lip486 with four commercial detergents were conducted. The results are shown in Figure 6. After soaking in various detergents for 30 min, the enzymatic activities of Lip486 soaked in Blue Moon detergent and Liyb detergent were obviously improved, especially in Blue Moon detergent. After soaking for 20 and 30 min, its enzyme activity was increased to 2.7 times and 2.6 times the original activity, respectively. Moreover, the enzyme activity of Lip486 increaased to 2.2 times of the original activity after immersion in Dettol hand sanitizer for $20 \mathrm{~min}$. However, the enzyme activity of Lip486 decreased after immersion in Dettol hand sanitizer for $10 \mathrm{~min}$ or $30 \mathrm{~min}$. In addition, the activity of Lip486 did not change significantly before and after soaking in Liby detergent but changed in Tide detergent. Lip486 activity could not be detected after brief immersion (10 min) in Tide detergent. However, after a long immersion time (30 min), its enzymatic activity gradually decreased to the level before immersion. The above results suggest that Lip486 can be used in various commercial detergents as long as the soaking time is properly controlled for different commercial detergents.

Determination of the ability of the recombinant Lip486 to remove oil stains from cotton cloth 
The effect of the recombinant Lip486 on removing oil stains is shown in Figure 7. Blue Moon detergent with no endogenous enzyme activity could not completely remove the oil stains on the cotton cloth (Figure 7B). With the addition of exogenous Lip486, the oil removal ability of Blue Moon detergent was significantly increased compared with that of the detergent alone (Figure 7B, Figure 7D). Lip486 removed oil stains on the cotton cloth even more effectively than endogenous lipase in Blue Moon detergent (Figure 7C, Figure 7D). These results indicate that Lip486 added to detergent can effectively remove oil stains on clothe; thus, it has the potential for application in the washing industry in the future.

\section{Discussion}

Functional metagenomic technology for new gene discovery based on changes in a clonal phenotype in a library is a powerful tool that allows us to identify new genes with low or even no homology to a reported gene sequence from the natural world (Cárcel-Márquez et al. 2019). To date, a large number of new lipases have been discovered from various habitats using functional metagenomic technology (Privé et al. 2015; Kim et al. 2015; Tang et al. 2017; Almeida et al. 2019; Sahoo et al. 2020). However, identifying a novel lipase that is completely distinct from the known lipase sequence with functional metagenomic technology is still very difficult. In this study, we used functional metagenomic technology to isolate a novel lipase gene from the sediment of papermaking wastewater, which has two main attractive features. First, it has very low homology to any reported lipase gene, and we consequently could not find similar genes using the BLAST tool. We could only verify its function through experiments and ultimately demonstrate that it may belong to a new subfamily of lipolytic enzyme families. To our knowledge, this is the first case of a novel lipase with no obvious homology to known lipases identified using metagenomic technology. This discovery not only enriches the species of lipase but also deepens our understanding of lipase. Second, the molecular weight of a lipase from bacteria is generally $19-60 \mathrm{kDa}$ (Okumura et al. 1976), while the molecular weight of Lip486 is only approximately $17 \mathrm{kDa}$, which is lower than those of most reported lipases. In general, enzymes with small-molecule weights have better stability, higher plasticity, and greater potential for industrial applications, and some related precedents have been reported. For example, Bhardwaj et al. reported a lipase derived from rice bran with a protein molecular weight of only $9.4 \mathrm{kDa}$; It had an optimal temperature of $80^{\circ} \mathrm{C}$ and an optimal $\mathrm{pH}$ of 11.0 and displayed good thermostability and alkali tolerance (Bhardwaj et al. 2001). In this study, the metagenome-derived lipase Lip486 had a molecular weight of $17.36 \mathrm{kDa}$, and its optimum temperature and $\mathrm{pH}$ were $53^{\circ} \mathrm{C}$ and 8.0 , respectively. Its residual enzyme activity was still greater than $60 \%$ after incubation at $60^{\circ} \mathrm{C}$ for $4 \mathrm{~h}$, and $60 \%$ of the remaining activity was maintained after incubation at $\mathrm{pH} 10.0$ for $4 \mathrm{~h}$. These properties are similar to those of the small-molecule lipase reported above. Lip486 has good thermostability and alkali resistance, high heterologous soluble expression ( $219.62 \mathrm{mg} / \mathrm{L})$, good specific enzyme activity $(51.80 \mathrm{U} / \mathrm{mg})$, and a low molecular weight, which facilitate the use of directed evolution technology to further modify the enzymatic properties of Lip486. Therefore, this enzyme has good application prospects in the washing industry.

The washing industry is an important application field for lipase. Surfactants play a major role in detergents. Therefore, a prerequisite for adding enzymes to detergents in the washing industry is good 
surfactant compatibility. Surfactants currently used in detergents are divided into ionic surfactants and nonionic surfactants. SDS is a typical anionic surfactant, while Tween-20 and Triton X-100 are two common nonionic surfactants. In this study, we explored the compatibility of Lip486 with these three common surfactants and compared Lip486's tolerance to these three surfactants with those of several lipases reported to have promising applications in the washing industry. The detailed results are shown in Table 4. Although the activity of lipase HML remained almost unchanged (Akmoussi-Toumi et al. 2018) and Lip486 was slightly inhibited by SDS, the activities of the other lipases were strongly inhibited by SDS (Sahoo et al. 2020; Gurkok and Ozdal 2021; Rmili et al. 2019; Sharma et al. 2017). In addition, most lipase activities were inhibited by Tween-20 (Sahoo et al. 2020; Gurkok and Ozdal 2021; Rmili et al. 2019), while only some were inhibited by Triton X-100 (Sahoo et al. 2020; Gurkok and Ozdal 2021). Lip486 displayed good tolerance to both surfactants, and its activity was substantially activated, reaching $322 \%$ and $684 \%$ of the original activity, respectively. Lip486's high tolerance to surfactants reflects its superiority over other lipases.

Table 4

Comparisons of enzymatic characteristics of several lipases related to detergent addition.

\begin{tabular}{|c|c|c|c|c|c|c|}
\hline Lipase name & $\begin{array}{l}\text { Optimum } \\
\text { temperature }\end{array}$ & $\begin{array}{l}\text { Optimum } \\
\text { pH }\end{array}$ & $\begin{array}{l}\text { Effect of } \\
\text { SDS on } \\
\text { enzyme } \\
\text { activity }\end{array}$ & $\begin{array}{l}\text { Effect of } \\
\text { Tween-20 } \\
\text { on } \\
\text { enzyme } \\
\text { activity }\end{array}$ & $\begin{array}{l}\text { Effect of } \\
\text { Triton X- } \\
100 \text { on } \\
\text { enzyme } \\
\text { activity }\end{array}$ & References \\
\hline Lip486 & $53^{\circ} \mathrm{C}$ & 8.0 & $\begin{array}{l}82.2 \%(5 \\
\mathrm{mM} \text { or } \\
0.144 \%)\end{array}$ & $\begin{array}{l}322.5 \% \\
(1 \%, w / v)\end{array}$ & $\begin{array}{l}684.3 \% \\
(1 \%, w / v)\end{array}$ & This study \\
\hline Lip479 & $65^{\circ} \mathrm{C}$ & 8.0 & $\begin{array}{l}0.273 \% \\
(1 \%, w / v)\end{array}$ & $\begin{array}{l}1.631 \% \\
(1 \%, w / v)\end{array}$ & $\begin{array}{l}2.487 \% \\
(1 \%, w / v)\end{array}$ & [22] \\
\hline HML & $60^{\circ} \mathrm{C}$ & 7.0 & $\begin{array}{l}101 \% \\
(1 \%, w / v)\end{array}$ & $\begin{array}{l}101 \%(1 \%, \\
w / v)\end{array}$ & $\begin{array}{l}102 \%(1 \% \\
w / v)\end{array}$ & [29] \\
\hline LipT51 & $60^{\circ} \mathrm{C}$ & 9.0 & $\begin{array}{l}27.8 \% \\
(10 \% \\
w / v)\end{array}$ & $\begin{array}{l}27.8 \% \\
(10 \% \\
w / v)\end{array}$ & $\begin{array}{l}36.1 \% \\
(10 \%, w / v)\end{array}$ & [30] \\
\hline SCL & $37^{\circ} \mathrm{C}$ & 8.5 & $\begin{array}{l}8 \%(1 \% \\
w / v)\end{array}$ & $\begin{array}{l}16 \%(1 \% \\
w / v)\end{array}$ & $\begin{array}{l}\sim 110 \% \\
(1 \%, w / v)\end{array}$ & [31] \\
\hline $\begin{array}{l}\text { Lipase of } \\
\text { Bacillus } \\
\text { methylotrophicus } \\
\text { PS3 }\end{array}$ & $55^{\circ} \mathrm{C}$ & 7.0 & $\begin{array}{l}10.71 \% \\
(1 \%, w / v)\end{array}$ & I & $\begin{array}{l}106.16 \% \\
(1 \%, w / v)\end{array}$ & [32] \\
\hline
\end{tabular}

The following factors should be considered when selecting an ideal enzyme additive for detergents: enzyme activity, tolerance under alkaline conditions, good compatibility with detergent ingredients and a high degreasing ability. To further explore the application potential of Lip486 as a detergent additive, we selected four mainstream commercial detergents in this study. After adding Lip486 to each detergent for 
different treatment times, we detected the residual enzyme activity and investigated the compatibility of the enzyme with the commercial detergents. The results indicated that the compatibility of Lip486 with the four kinds of detergents was generally good, and the residual enzyme activity was basically more than $50 \%$ of the highest activity after incubation for $3 \mathrm{~h}$. In addition, by simulating the normal detergent soaking process, we added Lip486 and four commercial detergents to tap water and detected the remaining enzyme activity after soaking for different times. The enzymatic activity of Lip486 was obviously improved after soaking in two detergents for $30 \mathrm{~min}$, especially in Blue Moon detergent. After soaking for $30 \mathrm{~min}$, the enzyme activity was increased to 2.6 times the original activity. These results suggest that as long as the soaking time is properly controlled, Lip486 can be added to many kinds of commercial detergents. Finally, we used a cotton cloth to conduct an oil removal test, which visually showed the oil removal effect of Lip486. Lip486 demonstrated better performance in removing oil stains on cotton cloth than the endogenous lipases in Blue Moon detergent. Based on the above results, Lip486 is consistent with the enzymatic characteristics of an ideal enzyme-containing detergent and has great potential for use as supplemental enzyme in detergents in the washing industry.

\section{Conclusion}

In this study, a metagenomic library of paper mill wastewater sediments was constructed, and a novel lipase gene (lip486) was obtained by functional screening. Then, the gene was efficiently expressed in $E$. coli. In addition, the enzymatic properties of Lip486 and its application prospects in the washing industry were also explored in detail. Interestingly, the protein encoded by this gene had a small molecular weight and no obvious homology to known lipase genes. The discovery of this gene not only demonstrates the role of functional metagenomic technology in discovering novel genes but also enriches the types of lipases and deepens our understanding of lipases. In addition, Lip486 has high enzyme activity, good alkali tolerance, and good compatibility with several mainstream commercial detergents and can improve the ability of commercial detergents to remove oil stains. Lip486 conforms to the enzymatic characteristics of an ideal enzyme-containing detergent and has good application prospects in the washing industry.

\section{Declarations}

\section{Conflict of interest}

We declare that we have no conflict of interest.

\section{Funding}

This work was supported by GDAS Special Project of Science and Technology Development (2019GDASYL-0501006); The Guangdong Basic and Applied Basic Research Foudation 
(2020A151501240); Research Programs of Guangdong Province (2017B020202005); The Research Programs of Guangzhou (202103000065).

\section{References}

1. Akmoussi-Toumi S, Khemili-Talbi S, Ferioune I, Kebbouche-Gana S (2018) Purification and characterization of an organic solvent-tolerant and detergent-stable lipase from Haloferax mediterranei CNCMM 50101. Int J Biol Macromol 116:817-830

2. Almeida JM, Martini VP, lulek J, Alnoch RC, Moure VR, Müller-Santos M, Souza EM, Mitchell DA, Krieger N (2019) Biochemical characterization and application of a new lipase and its connate foldase obtained from a metagenomic library derived from fat-contaminated soil. Int J Biol Macromol 137:442-454

3. Bharathi D, Rajalakshmi G (2019) Microbial lipases: an overview of screening, production and purification. Biocatal Agric Biotechnol 22:101368

4. Bhardwaj K, Raju A, Rajasekharan R (2001) Identification, purification, and characterization of a thermally stable lipase from rice bran. A new member of the (phospho) lipase family. Plant Physiol 127:1728-1738

5. Cárcel-Márquez J, Flores A, Martín-Cabello G, Santero E, Camacho EM (2019) Development of an inducible lytic system for functional metagenomic screening. Sci Rep 9:3887

6. Casas-Godoy L, Duquesne S, Bordes F, Sandoval G, Marty A (2012) Lipases: an overview. Methods Mol Biol 861:3-30

7. Contesini FJ, Lopes DB, Macedo GA, Nascimento MG, Carvalho PO (2010) Aspergillus sp. lipase: potential biocatalyst for industrial use. J Mol Catal B Enzym 67:163-171

8. Gricajeva A, Bendikienè V, Kalèdienè L (2016) Lipase of Bacillus stratosphericus L1: Cloning, expression and characterization. Int J Biol Macromol 92:96-104

9. Gurkok S, Ozdal M (2021) Purification and characterization of a novel extracellular, alkaline, thermoactive, and detergent-compatible lipase from Aeromonas caviae LipT51 application in detergent industry. Protein Expr Purif 180:105819

10. Jaeger KE, Reetz MT (1998) Microbial lipases form versatile tools for biotechnology. Trends Biotechnol 16:396-403

11. Käll L, Krogh A, Sonnhammer EL (2004) A combined transmembrane topology and signal peptide prediction method. J Mol Biol 338:1027-1036

12. Kim HJ, Jeong YS, Jung WK, Kim SK, Lee HW, Kahng HY, Kim J, Kim H (2015) Characrerization of novel family IV esterase and family I.3 lipase from an oil-polluted mud flat metagenome. Mol Biotechnol 57:781-792

13. Kumar S, Stecher G, Tamura K (2016) MEGA7: molecular evolutionary genetics analysis version 7.0 for bigger datasets. Mol Biol Evol 33:1870-1874 
14. Madhavan A, Sindhu R, Parameswaran B, Sukumaran RK, Pandey A (2017) Metagenome analysis: a powerful tool for enzyme bioprospecting. Appl Biochem Biotechnol 183:636-651

15. Martínez-Ruiz A, Tovar-Castro L, García HS, Saucedo-Castañeda G, Favela-Torres E (2018) Continuous ethyl oleate synthesis by lipase produced by solid-state fermentation by Rhizopus microsporus. Bioresour Technol 265:52-58

16. Milferstedt K, Godon JJ, Escudié R, Prasse S, Neyret C, Bernet N (2012) Heterogeneity and spatial distribution of bacterial background contamination in pulp and process water of a paper mill. $\mathrm{J}$ Ind Microbiol Biotechnol 39:1751-1759

17. Navvabi A, Razzaghi M, Fernandes P, Karami L, Homaei A (2018) Novel lipases discovery specifically from marine organisms for industrial production and practical applications. Process Biochem 70:61-70

18. Ngara TR, Zhang H (2018) Recent advances in function-based metagenomic screening. Genomics Proteomics Bioinformatics 16:405-415

19. Niyonzima FN, More SS (2014) Concomitant production of detergent compatible enzymes by Bacillus flexus XJU-1. Braz J Microbiol 45:903-910

20. Okumura S, Iwai M, Tsujisaka Y (1976) Positional specificities of four kinds of microbial lipases. Agric Biol Chem 40:655-660

21. Patel N, Rai D, Shivam, Shahane S, Mishra U (2019) Lipases: sources, production, purification, and applications. Recent Pat Biotechnol 13:45-56

22. Petersen TN, Brunak S, von Heijne G, Nielsen H (2011) SignalP 4.0: discriminating signal peptides from transmembrane regions. Nat Methods 8:785-786

23. Phukon LC, Chourasia R, Kumari M, Godan TK, Sahoo D, Parameswaran B, Rai AK (2020) Production and characterisation of lipase for application in detergent industry from a novel Pseudomonas helmanticensis HS6. Bioresour Technol 309:123352

24. Privé F, Newbold CJ, Kaderbhai NN, Girdwood SG, Golyshina OV, Golyshin PN, Scollan ND, Huws SA (2015) Isolation and characterization of novel lipases/esterases from a bovine rumen metagenome. Appl Microbiol Biotechnol 99:5475-5485

25. Priyanka P, Tan Y, Kinsella GK, Henehan GT, Ryan BJ (2019) Solvent stable microbial lipases: current understanding and biotechnological applications. Biotechnol Lett 41:203-220

26. Rmili F, Achouri N, Smichi N, Krayem N, Bayoudh A, Gargouri Y, Chamkha M, Fendri A (2019) Purification and biochemical characterization of an organic solvent-tolerant and detergent-stable lipase from Staphylococcus capitis. Biotechnol Prog 35:e2833

27. Sahoo RK, Das A, Sahoo K, Sahu A, Subudhi E (2020) Characterization of novel metagenomicderived lipase from Indian hot spring. Int Microbiol 23:233-240

28. Salihu A, Alam MZ (2015) Solvent tolerant lipases: a review. Process Biochem 50:86-96

29. Sharma P, Sharma N, Pathania S, Handa S (2017) Purification and characterization of lipase by Bacillus methylotrophicus PS3 under submerged from fermentation and its application in detergent 
industry. J Genet Eng Biotechnol 15:369-377

30. Tang L, Xia Y, Wu X, Chen X, Zhang X, Li H (2017) Screening and characterization of a novel thermostable lipase with deterget-addtive potential from the metagenomic library of a mangrove soil. Gene 625:64-71

31. Torsvik V, Sørheim R, Goksøyr J (1996) Total bacterial diversity in soil and sediment communities- a review. J Ind Microbiol Biotechnol 17:170-178

32. Ugo AK, Amara AV, Kenechuwku U, Igwe CN (2017) Microbial lipases: a prospect for biotechnological industrial catalysis for green products: a review. Ferment Technol 6:144-155

\section{Figures}

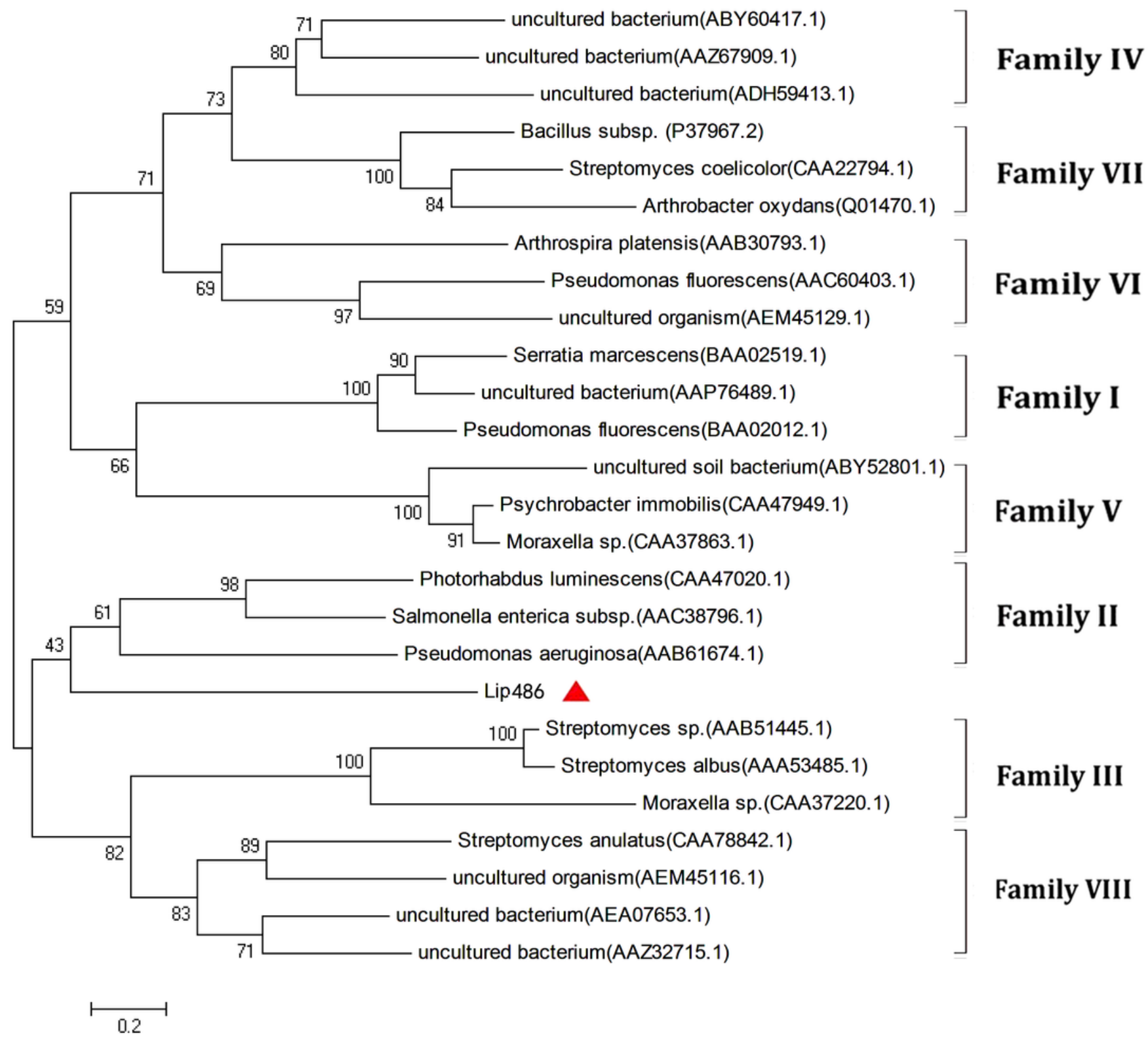

Figure 1 
Phylogenetic analysis of Lip486 and closely related lipolytic enzymes. The phylogenetic tree was constructed using MEGA 7.0 software by neighbor-joining method. The lipolytic enzyme sequences compared with Lip486 were obtained from GenBank. The units at the bottom of the tree indicate the number of substitution events. The number near a branch shows percentage of reliability in bootstrap test of this branch.

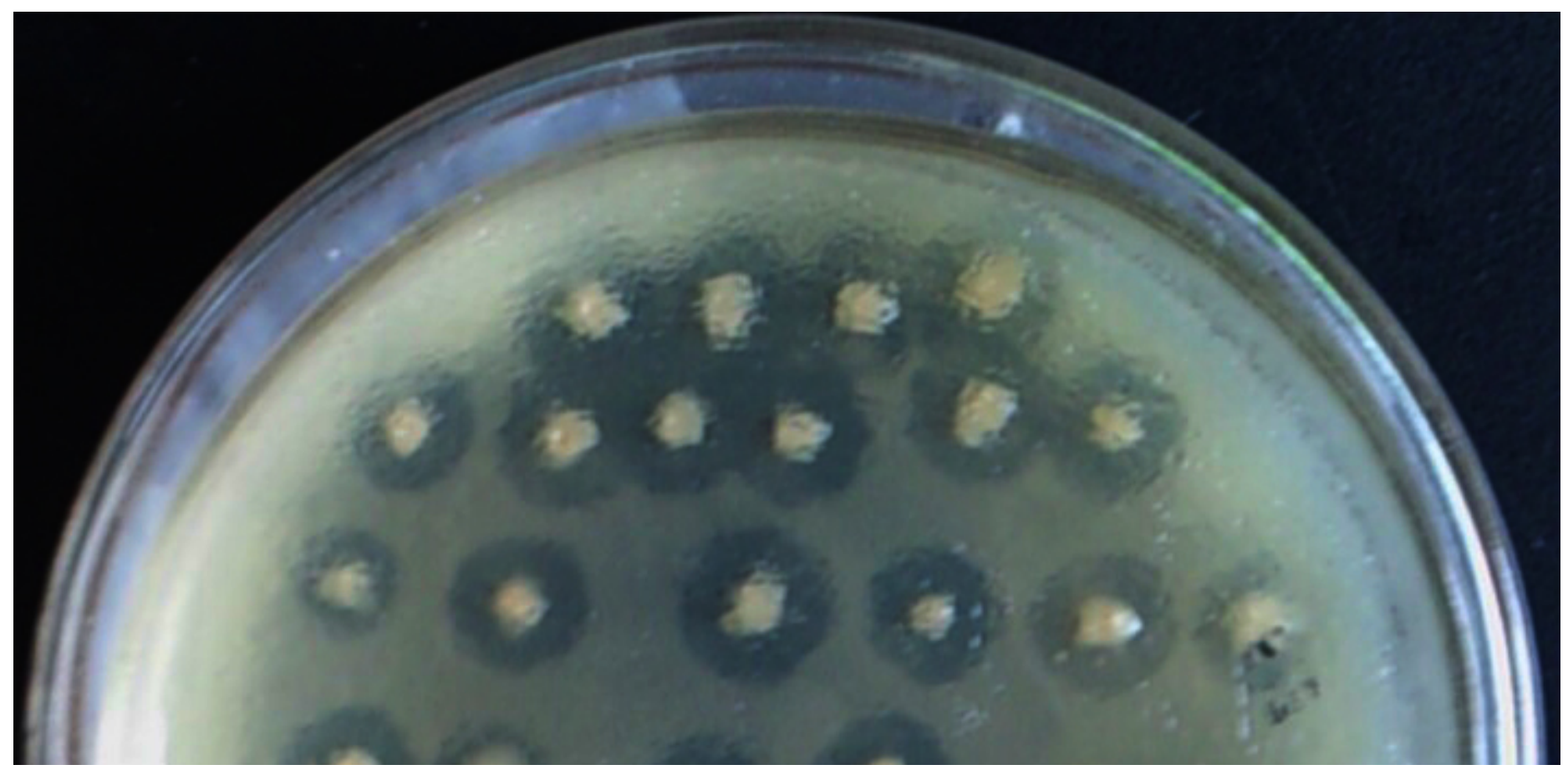

Figure 2

The recombinant clones carrying lip486 gene produced clear hydrolytic cycles on tributyrin screening plate. 

$\mathrm{kDa}$
M1
2
3

66. 2

45. 0-

35. $0-$

25. $0-$
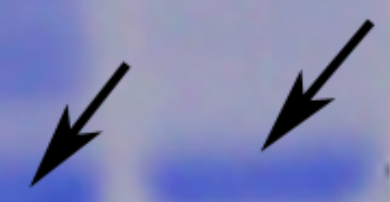

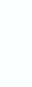



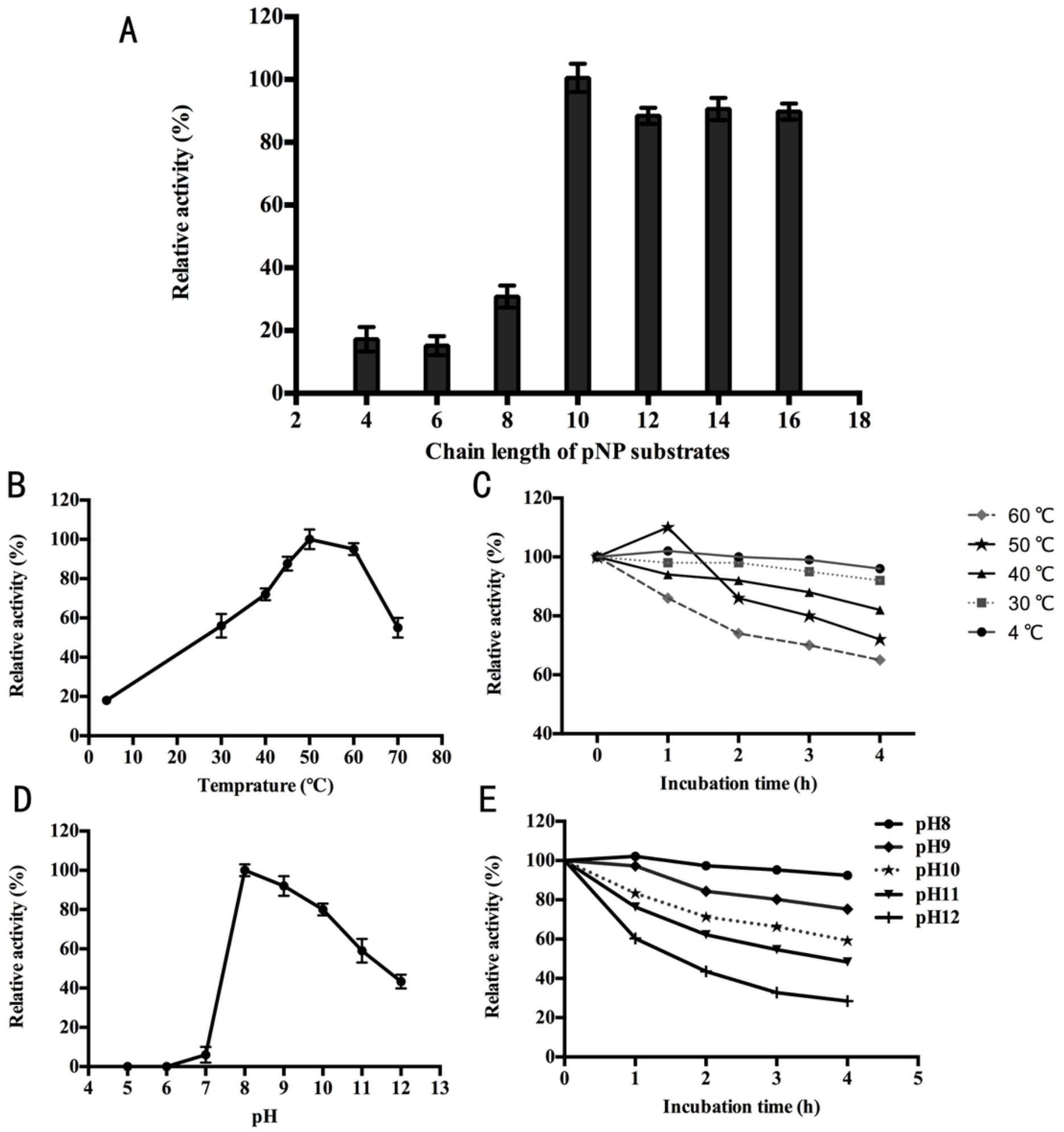

Figure 4

Characterization of Lip486. (A) Substrate specificity of Lip486. The enzymatic activity of Lip486 was tested towards $p$-nitrophenol esters with different chain lengths: p-nitrophenyl butyrate (C4), p-nitrophenyl caproate (C6), p-nitrophenyl octanoatee (C8), p-nitrophenyl caprate (C10), p-nitrophenyl laurate (C12), pnitrophenyl myristate (C14), p-nitrophenyl palmitate (C16). The activity of Lip486 towards $\mathrm{C} 10$ was regarded as $100 \%$. (B) Effects of temperature on the activity of Lip486 using p-nitrophenyl caprate as 
substrate. (C) Effects of temperature on the stability of Lip486 using p-nitrophenyl caprate as substrate. (D) Effects of pH on the activity of Lip486 using p-nitrophenyl caprate as substrate. (E) Effects of pH on the stability of Lip486 using p-nitrophenyl caprate as substrate. Data points in figure 4 are the average of triplicate experiments, and error bars represent standard deviation.

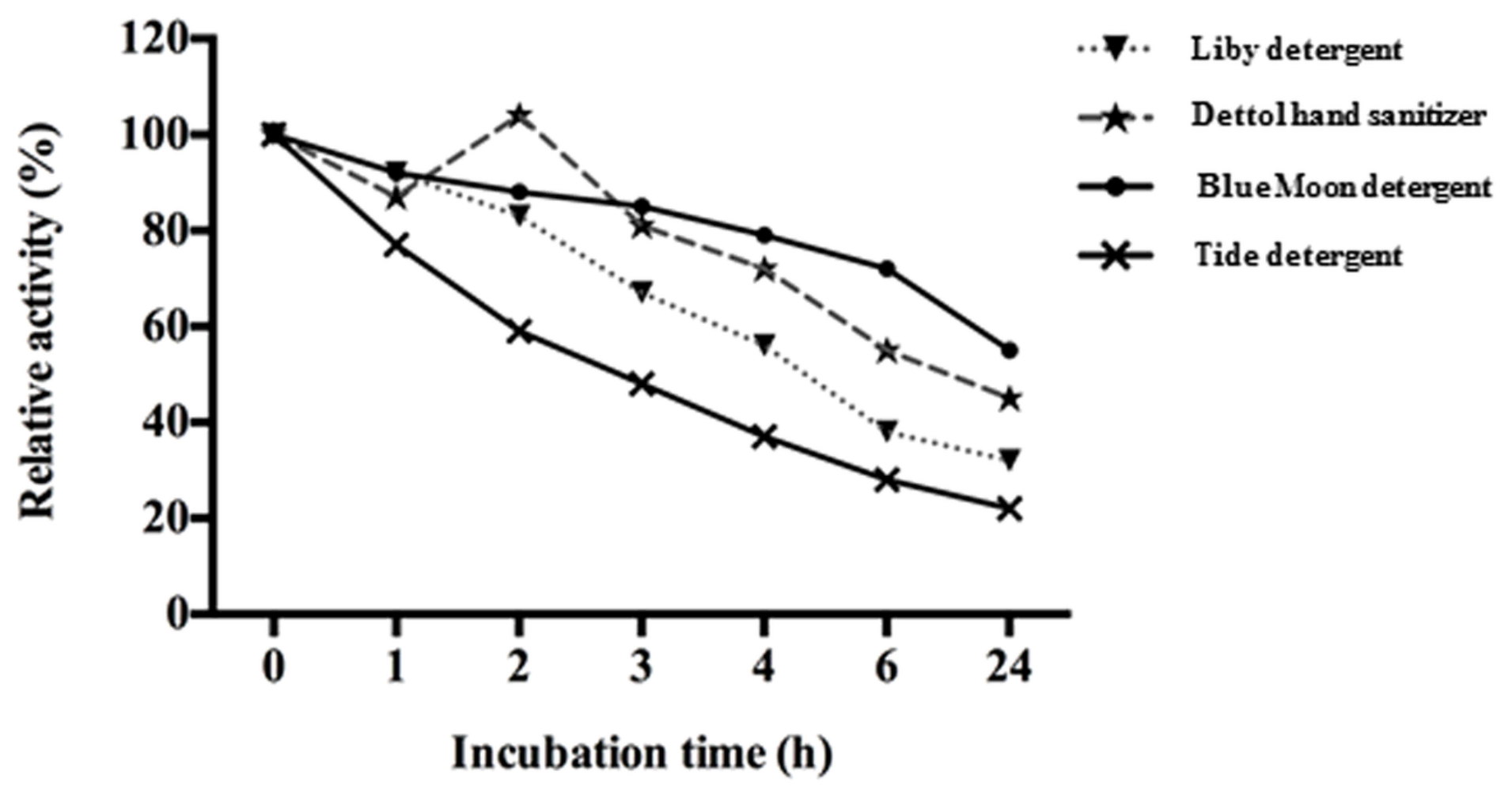

Figure 5

Compatibility test of recombinant Lip486 with four commercial detergents. The enzymatic activity in the absence of detergent was defined as $100 \%$. Data ponts are the average of triplicate experiments. 

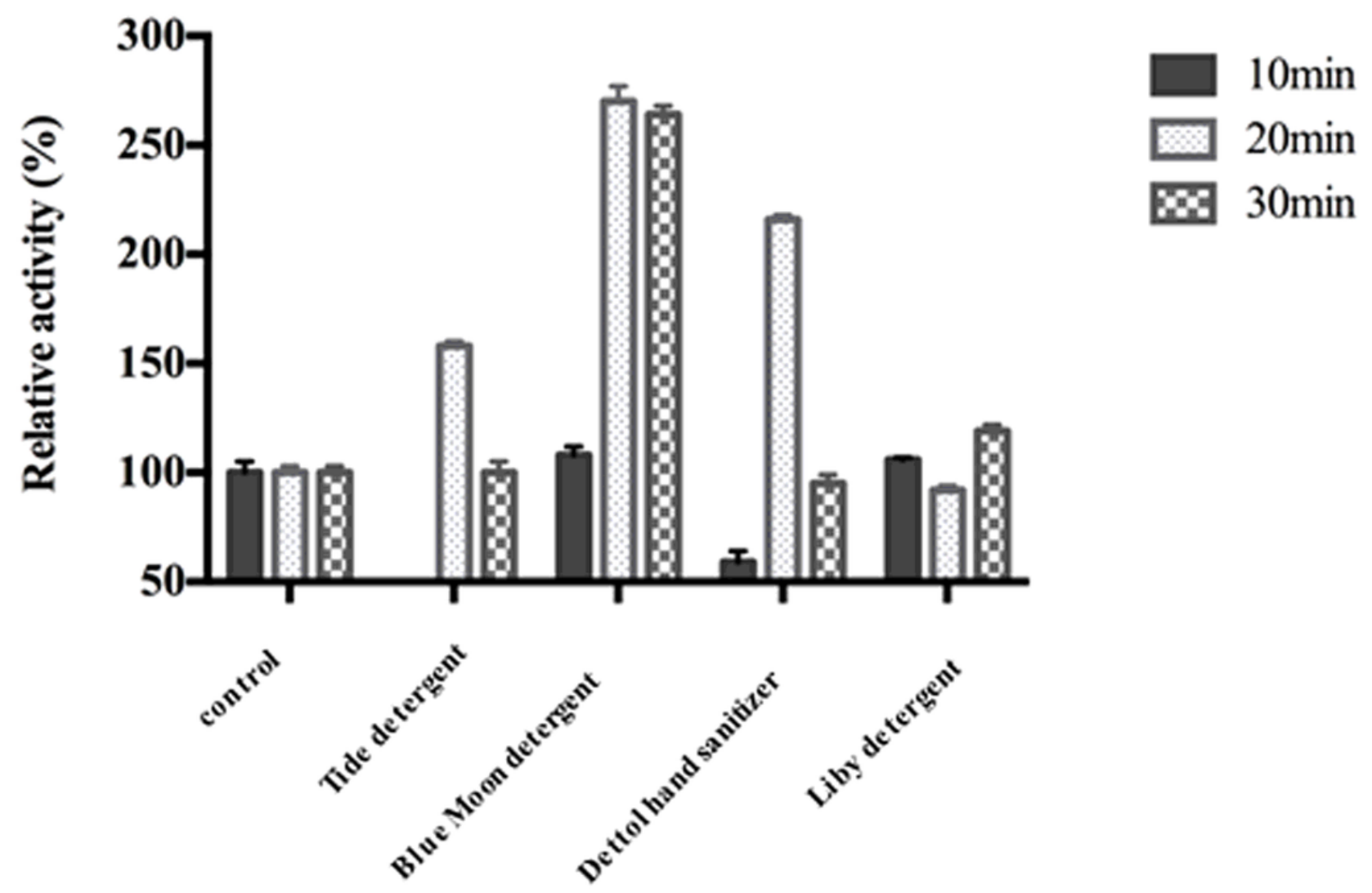

Figure 6

Immersion test of the recombinant Lip486 in four commercial detergents. The enzymatic activity in the absence of detergent was defined as $100 \%$. Data points are the average of triplicate experiments, and error bars represent standard deviation.

政

Figure 7

Washing performance of purified Lip486 for oil-stained cloth. (A) Oil-stained cloth washed with only tap water; (B) Oil-stained cloth washed with tap water and thermally deactivated Blue Moon detergent ( $0.2 \%)$; (C) Oil-stained cloth washed with tap water and Blue Moon detergent; (D) Oil-stained cloth washed with tap water, thermally deactivated Blue Moon detergent $(0.2 \%)$, and Lip486 solution $(0.5 \mathrm{~mL}, 10 \mathrm{U})$. 